\title{
Survival advantage observed with the use of metformin in patients with type II diabetes and colorectal cancer
}

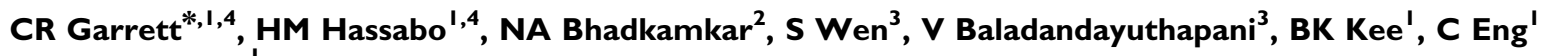 \\ and MM Hassan'
}

'Department of Gastrointestinal Medical Oncology, MD Anderson Cancer Center, Unit 426, 1515 Holcombe Boulevard, Houston, TX, 77030-4009, USA; ${ }^{2}$ Department of General Oncology, MD Anderson Cancer Center, Unit 462, 1515 Holcombe Boulevard, Houston, TX 77030-4009, USA;

${ }^{3}$ Department of Biostatistics, MD Anderson Cancer Center, Unit 1411, 1515 Holcombe Boulevard, Houston, TX, 77030-4009, USA

\begin{abstract}
BACKGROUND: Patients with type II diabetes mellitus (DM) have an increased risk of adenomatous colorectal (CRC) polyps and CRC cancer. The use of the anti-hyperglycemic agent metformin is associated with a reduced incidence of cancer-related deaths.

METHODS: We retrospectively evaluated the medical records of 4758 patients seen at a single institution and determined that 424 patients were identified by their physicians as having type II DM and CRC cancer. Data were subsequently acquired determining the subject's age, body mass index (BMI), and disease date of diagnosis, stage, site of cancer, treatment, and survival.

RESULTS: Patients with type II DM and CRC cancer treated with metformin as one of their diabetic medications had a survival of 76.9 months $(95 \% \mathrm{Cl}=61.4-102.4)$ as compared with 56.9 months in those patients not treated with metformin $(95 \% \mathrm{Cl}=44.8-68.8)$, $P=0.048$. By using a multivariable Cox regression model adjusted for age, sex, race, BMI, and initial stage of disease, we demonstrated that type II diabetic patients treated with metformin had a $30 \%$ improvement in overall survival (OS) when compared with diabetic patients treated with other diabetic agents.

CONCLUSION: Colorectal cancer patients with DM treated with metformin as part of their diabetic therapy appear to have a superior OS. British Journal of Cancer (2012) I 06, 1374-1378. doi:I0.1038/bjc.2012.7I www.bjcancer.com
\end{abstract}

Published online 15 March 2012

(c) 2012 Cancer Research UK

Keywords: colorectal cancer; metformin; diabetes; overall survival; retrospective review

Diabetes mellitus (DM), specifically type II DM, is associated with an increased risk of cancer, particularly pancreas, liver, endometrium, breast, bladder, and colorectal (CRC; Vigneri et al, 2009). This increased risk observed is independent of age and body mass index (BMI). A meta-analysis of 15 studies involving a total of 2593935 participants demonstrated that the relative risk of CRC in type II DM patients compared with those without the disease was 1.30 (95\% CI $=1.2-1.4$; Larsson et al, 2005). Type II DM patients with poor glycemic control, as measured by glycosylated haemoglobin (HbAlc), have a greater prevalence of right-sided adenomatous polyps, a greater number of polyps, and a greater number of adenomatous polyps (Siddiqui et al, 2008). The cause for the increased risk of cancer in type II DM patients is not clearly understood but may be related to dietary-induced elevated insulin (Venkateswaran et al, 2007) and elevated insulin-like growth factor-I levels (Ma et al, 1999). Insulin is a humeral growth factor for a variety of cancer cells in vitro, and a variety of therapies targeting the insulin-like growth factor receptor are undergoing evaluation as potential anti-cancer treatment (Maki, 2010; Golan and Javle, 2011).

Metformin is a biguanide widely used to decrease plasma glucose levels by increasing intracellular glucose uptake (Bailey and Turner, 1996). Type II DM population studies demonstrate that patients who use only metformin for management of their DM

\footnotetext{
*Correspondence: Dr CR Garrett; E-mail: cgarrett@mdanderson.org

${ }^{4}$ These authors contributed equally to this work

Revised I4 February 2012; accepted 17 February 2012; published online I5 March 2012
}

have a lower cancer risk $(1.08, \mathrm{CI}=0.96-1.21)$ compared with those treated with metformin plus a sulphonylurea $(1.36,95 \%$ $\mathrm{CI}=1.19-1.54)$, vs those on insulin-based regimes $(1.42,95 \%$ $\mathrm{CI}=1.27-1.60$; Currie et al, 2009). Metformin has been associated with a lower cancer mortality in type II DM as compared with its non-use (Landman et al, 2010). In Korean patients with CRC, a recent report (Lee et al, 2011) indicated that metformin use was associated with lower risk of overall mortality, especially patients with stage III. The current study aimed to assess such association in US patients after controlling for confounding effect of several factors related to CRC survival.

\section{MATERIALS AND METHODS}

Under an Institutional Review Board approved protocol (designated DR09-1719) the electronic records of 4758 patients with a diagnostic code of colon cancer or rectal cancer seen at a single institution (MD Anderson) from 1 January 2004 to 31 December 2008 were reviewed. All patients were diagnosed with pathologically confirmed CRC and were evaluated at their baseline visit to MD Anderson for appropriate staging according to Tumour/Node/ Metastatic (TNM) scoring systems staging. Structured data collection sheet was developed to retrieve epidemiological and clinical factors. A manual retrospective review was conducted for all patients to identify those with prior history of DM.

Of these 4758 patients, 424 were identified by their cancer physician at the time of their initial consultation as having type II 
DM treated with diet, medication, or insulin (or a combination of these therapies); patients identified as having type I DM were excluded from this analysis. Only patients who resided in the United States were included in this study. Patients were identified by review of outside records as having type II DM; additional confirmatory testing was not routinely performed. Follow-up information for survival was available in 397 patients. Date of diagnosis, patient's age, height, weight, and BMI at the time of diagnosis were recorded. Body mass index were stratified into 'underweight' (BMI<18.5), 'normal' (BMI range: 18.5-24.9), 'overweight' (BMI range: 25.0-29.9), and 'obese' (BMI $\geqslant 30.0)$. A total of 13 patients referred to MD Anderson without baseline images including computed tomography scan, magnetic resonance imaging and were excluded from the analysis. Tumour-specific informations, including size, pathologic stage, lymphovascular invasion, as well as adjuvant and metastatic cancer therapies, were abstracted from the medical record. Diabetic medications, glycosylated haemoglobin (HbAlc), and anti-cholesterol medications were also noted. The pathologic response rate following chemoradiation therapy for rectal cancers and perioperative chemotherapy for hepatic metastases undergoing surgical resection were noted.

\section{Statistical considerations}

All clinical and epidemiological data were merged and analysed with use of STATA software (STATA Corp., College Station, TX, USA). Overall survival (OS) was defined as the time between dates of CRC diagnosis and death or end of follow-up (censored observations). Median survival was estimated by using the Kaplan-Meier product-limit method, and significant differences in survival times among CRC with and without DM and different DM treatment were determined by using the log-rank test. Hazard ratios (HRs) and 95\% CIs were calculated by using Cox proportional hazard models with a backward stepwise selection procedure, considering the clinical co-variates of CRC. Univariate analyses were conducted with $\chi^{2}$ or Fisher exact tests for categorical variables and the Kruskal-Wallis test for continuous variables.

\section{RESULTS}

Among 4758 CRC patients the prevalence of type II DM was $8.9 \%$ (424 patients); the overall mean age ( \pm s.d.) was 62.7 years $( \pm 10.2)$. Men to women ration were approximately $2: 1$. Majority of patients were white, which was consistent with referral pattern of MD Anderson Cancer Center. Table 1 showed the demographic and clinical features of CRC patients with type II DM stratified by metformin intake. We found no significant difference between both groups. International patients, for whom follow-up data would not be available, were not included in this analysis. The types of anti-diabetic medications administered to the patients are demonstrated in Figure 1. There was a slight preponderance of patients not receiving metformin in 2005, with relatively equal distribution in the years 2006-2008 (see Figure 2). HbAlc was performed at the time of the initial consultation in 118 patients (28\%); median $\mathrm{HbAlc}$ was $7.2 \%$ (range $4.9-12.9 \%$ ). Aspirin was used at the time of original evaluation at MD Anderson in 119 of 424 patients (28.1\%); there was no significant difference in aspirin use in CRC diabetic patients treated with and without metformin, $P=0.3$ (Table 2). Anti-cholesterol therapy at the time of the patient's first evaluation was $43 \%$ and was slightly higher in the non-metformin group when compared with the metformin group (47\% vs 39\%).

For survival analysis, death was confirmed for 194 CRC patients (45.8\%); the median OS was 70.7 months (95\% CI $=62.3-79.1)$. Patients with type II DM and CRC treated with metformin had significantly longer OS of 82.5 months $(95 \% \mathrm{CI}=69.9-94.9)$ as compared with 60.9 months in patients not treated with metformin
Table I Characteristics of type 2 DM patients with CRC by their intake of metformin

\begin{tabular}{|c|c|c|c|c|c|c|}
\hline \multirow[b]{2}{*}{ Variable } & \multirow[b]{2}{*}{ Variable label } & \multicolumn{2}{|c|}{$\begin{array}{l}\text { Metformin } \\
\text { users }\end{array}$} & \multicolumn{2}{|c|}{$\begin{array}{l}\text { Non- } \\
\text { metformin } \\
\text { users }\end{array}$} & \multirow[b]{2}{*}{$P$-value } \\
\hline & & $N=208$ & $\%$ & $N=216$ & $\%$ & \\
\hline Sex & $\begin{array}{l}\text { Male } \\
\text { Female }\end{array}$ & $\begin{array}{r}141 \\
67\end{array}$ & $\begin{array}{l}67.8 \\
32.2\end{array}$ & $\begin{array}{r}142 \\
74\end{array}$ & $\begin{array}{l}65.7 \\
34.3\end{array}$ & 0.7 \\
\hline Age (years) & $\begin{array}{l}\leqslant 50 \\
51-59 \\
60-69 \\
>70\end{array}$ & $\begin{array}{l}21 \\
70 \\
74 \\
43\end{array}$ & $\begin{array}{l}10.1 \\
33.7 \\
35.6 \\
20.7\end{array}$ & $\begin{array}{l}25 \\
64 \\
71 \\
56\end{array}$ & $\begin{array}{l}11.6 \\
29.6 \\
32.9 \\
25.9\end{array}$ & 0.7 \\
\hline Race & $\begin{array}{l}\text { White } \\
\text { African Americans } \\
\text { Hispanics } \\
\text { Asians }\end{array}$ & $\begin{array}{r}142 \\
27 \\
26 \\
13\end{array}$ & $\begin{array}{l}68.3 \\
13 \\
12.5 \\
6.3\end{array}$ & $\begin{array}{r}145 \\
30 \\
32 \\
9\end{array}$ & $\begin{array}{r}67.1 \\
13.9 \\
14.8 \\
4.2\end{array}$ & 0.7 \\
\hline BMI Status & $\begin{array}{l}\text { Underweight/normal } \\
\text { Overweight } \\
\text { Obese }\end{array}$ & $\begin{array}{r}45 \\
62 \\
101\end{array}$ & $\begin{array}{l}21.6 \\
29.8 \\
48.6\end{array}$ & $\begin{array}{r}44 \\
67 \\
105\end{array}$ & $\begin{array}{l}20.4 \\
31 \\
48.6\end{array}$ & 0.9 \\
\hline Aspirin intake & $\begin{array}{l}\text { No } \\
\text { Yes }\end{array}$ & $\begin{array}{r}145 \\
63\end{array}$ & $\begin{array}{l}69.7 \\
30.3\end{array}$ & $\begin{array}{r}160 \\
56\end{array}$ & $\begin{array}{l}74.1 \\
25.9\end{array}$ & 0.3 \\
\hline TNM staging ${ }^{\mathrm{a}}$ & $\begin{array}{l}\text { Stage I-II } \\
\text { Stage III } \\
\text { Stage IV }\end{array}$ & $\begin{array}{l}48 \\
80 \\
74\end{array}$ & $\begin{array}{l}23.8 \\
36.9 \\
36.6\end{array}$ & $\begin{array}{l}46 \\
92 \\
71\end{array}$ & $\begin{array}{l}22 \\
44 \\
34\end{array}$ & 0.6 \\
\hline Cancer site ${ }^{a}$ & $\begin{array}{l}\text { Rectum } \\
\text { Recto-sigmoid } \\
\text { Sigmoid } \\
\text { Ascending } \\
\text { Transverse } \\
\text { Descending } \\
\text { Synchronous }\end{array}$ & $\begin{array}{r}58 \\
19 \\
48 \\
47 \\
19 \\
8 \\
3\end{array}$ & $\begin{array}{r}27.9 \\
9.1 \\
23.1 \\
22.6 \\
9.1 \\
3.8 \\
1.4\end{array}$ & $\begin{array}{r}71 \\
17 \\
45 \\
40 \\
22 \\
11 \\
3\end{array}$ & $\begin{array}{r}32.9 \\
7.9 \\
20.8 \\
18.5 \\
10.2 \\
5.1 \\
1.4\end{array}$ & 0.9 \\
\hline
\end{tabular}

Abbeviations: $\quad \mathrm{BMI}=$ body mass index; $\quad \mathrm{CRC}=$ colorectal; $\quad \mathrm{DM}=$ diabetes; TNM = tumour/node/metastatic. ${ }^{a}$ Thirteen patients (six from metformin users and seven from non-metformin users) without baseline imaging (computed tomography or magnetic resonance imaging)

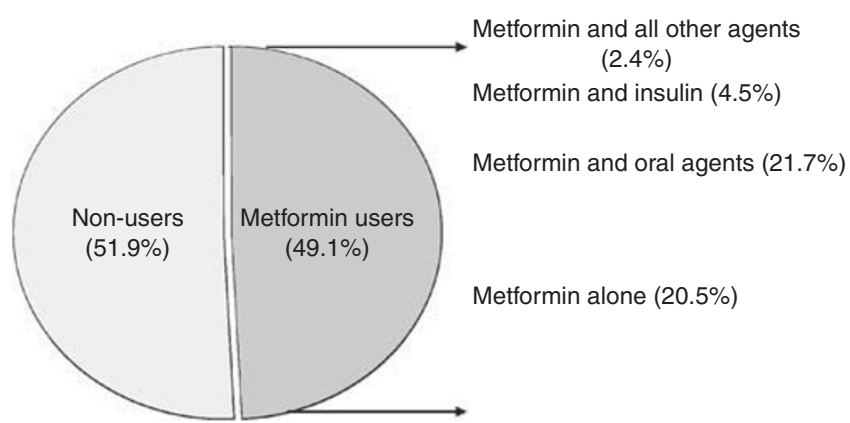

Figure I Distribution of metformin intake in patients with CRC.

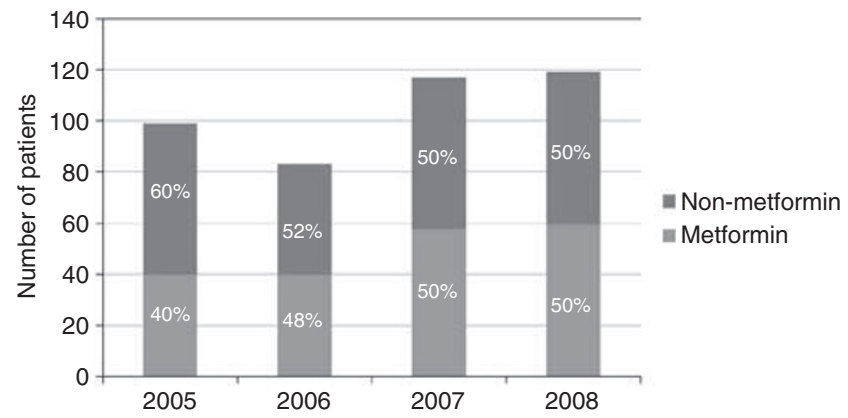

Figure 2 Metformin usage (by calendar year). 
Table 2 Survival prediction of metformin intake: adjusted HR using Cox regression $^{\mathrm{a}}$

\begin{tabular}{|c|c|c|c|}
\hline Variable & Variable label & HR $(95 \% \mathrm{Cl})$ & $P$-value \\
\hline Sex & $\begin{array}{l}\text { Male } \\
\text { Female }\end{array}$ & $\begin{array}{c}\text { I (Reference) } \\
0.8(0.6-1.1)\end{array}$ & 0.07 \\
\hline Age categories & $\begin{array}{l}\leqslant 50 \\
51-60 \\
61-70 \\
>70\end{array}$ & $\begin{array}{c}\text { I (Reference) } \\
0.8(0.5-1.2) \\
1.1(0.7-1.7) \\
1.2(0.8-1.9)\end{array}$ & $\begin{array}{l}0.5 \\
0.5 \\
0.2\end{array}$ \\
\hline Race & $\begin{array}{l}\text { Non-white } \\
\text { White }\end{array}$ & $\begin{array}{c}\text { I (Reference) } \\
0.9(0.7-1.3)\end{array}$ & 0.6 \\
\hline $\begin{array}{l}\text { BMI } \\
\text { Aspirin intake }\end{array}$ & $\begin{array}{l}\text { No } \\
\text { Yes }\end{array}$ & $\begin{aligned} \mid & (0.9-1.1) \\
\mid & \text { (Reference) } \\
0.8 & (0.6-1.1)\end{aligned}$ & $\begin{array}{l}0.9 \\
0.3\end{array}$ \\
\hline Staging category & $\begin{array}{l}\text { Stage I-II } \\
\text { Stage III } \\
\text { Stage IV }\end{array}$ & $\begin{array}{l}\text { I (Reference) } \\
\text { 1.6 (1.02-2.4) } \\
5.6(3.7-8.4)\end{array}$ & $\begin{array}{l}0.04 \\
0.0001\end{array}$ \\
\hline Metformin intake & $\begin{array}{l}\text { No } \\
\text { Yes }\end{array}$ & $\begin{array}{c}\text { I (Reference) } \\
0.6(0.5-0.8)\end{array}$ & 0.001 \\
\hline
\end{tabular}

Abbreviations: $\mathrm{BMI}=$ body mass index; $\mathrm{Cl}=$ confidence iterval; $\mathrm{HR}=$ hazard ratio ${ }^{a}$ Adjusted for age, sex, race, BMI, aspirin usage, and tumour/node/metastatic staging. The bold values are statistically significant.

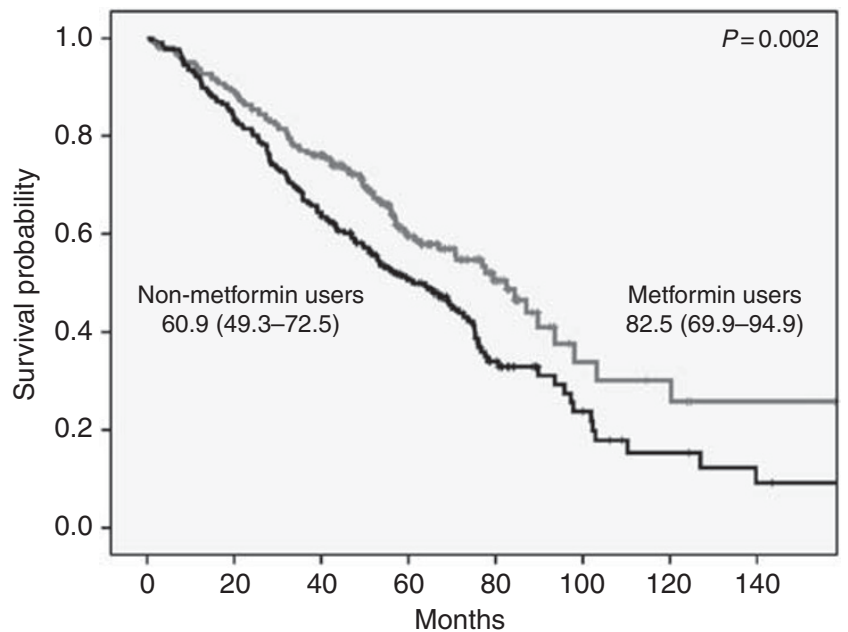

Figure 3 Figure 2: Overall median survival $(95 \% \mathrm{Cl})$ in months with comparison between metformin and non-metformin users in all patients with CRC.

(95\% CI $=49.3-72.5$ ), $P=0.002$ (Figure 3). The significant difference between metformin- and non-metformin-treated patients was observed in patients with TNM stage I-II and in patients with TNM-stage III (Figure 4). The estimated median OS times (95\% CI) were 89.7 (54.6-124.8) compared with 71.5 (63.8-79.2), $P=0.002$. However, survival of metformin-treated patients with stage I-II did not reach the median. No significant difference was observed in advanced stage CRC patients (Stage IV). There was a non-statistical significant trend towards a higher complete and minor pathologic response rate $(\leqslant 10 \%$ residual tumour) in type II DM patients with rectal cancer receiving neoadjuvant chemoradiation who were treated with metformin vs those who were not $(14 / 19,74 \%$ vs $9 / 19,47 \%, P=0.09)$. Adjusting for age, sex, race, BMI, aspirin usage, and initial stage of disease indicated that type II DM patients with CRC treated with metformin had a $40 \%$ improvement in OS when compared with type II DM patients treated with other anti-diabetic agents. The estimated HR (95\% CI) was $0.6(0.5-0.8)$. Including BMI as continuous or
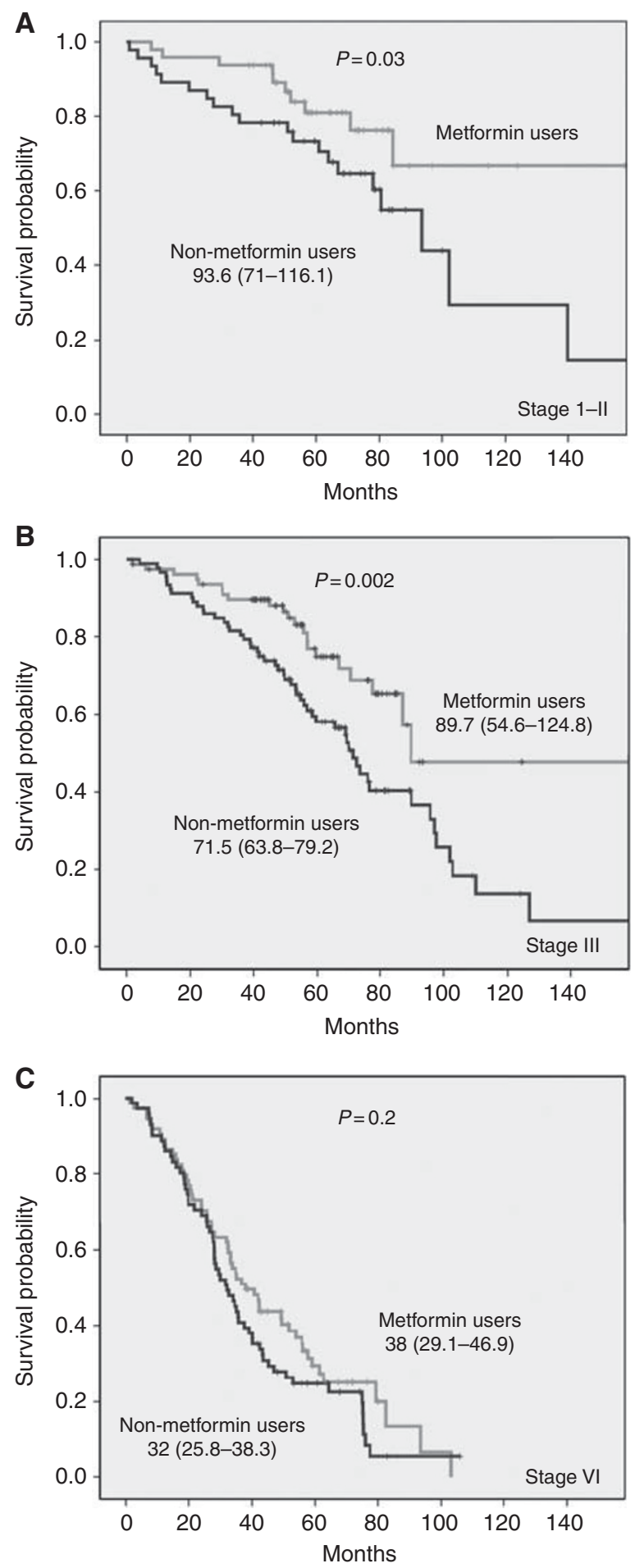

Figure 4 Overall median survival $(95 \% \mathrm{Cl})$ in months with comparison between metformin and non-metformin users stratified by TNM staging in all patients with CRC: A (stage I-II), B (stage III), C (stage IV).

categorical variable did not meaningfully change the observed lack of predictive role of baseline obesity on the OS of CRC patients.

\section{DISCUSSION}

Of 424 patients with CRC cancer, we found a prevalence of type II DM of $8.9 \%$; this is similar to other reports, which noted a 
prevalence of 11\% (Lee et al, 2011), 7.9\% (Meyerhardt et al, 2003), and $9.6 \%$ (van de Poll-Franse et al, 2007). In this retrospective analysis, the use of metformin in type II DM patients with CRC was associated with an improved OS. This retrospective analysis is limited by the fact that data were not present regarding the date of onset of DM as well as the duration of exposure of the patient to metformin; a carefully controlled prospective study would be required to confirm these preliminary results. The median 5-year OS of $50 \%$ is somewhat lower than the 63\% 5-year survival reported from Surveillance, Epidemiology, and End Results data 2004-2008 (SEER, 2011) and likely reflects the referral bias (patients with more advanced stage and with refractory disease being referred to a quaternary cancer centre). Although subject to all of the limitations of a retrospective analysis, the findings are consistent with data from other solid tumours including CRC cancer. Metformin usage has been shown to reduce cancer-specific and overall mortality in patients with type II DM on metformin compared with diabetic patients not taking metformin (Lee et al, 2011). The use of metformin in diabetic patients has been associated with a decreased risk of pancreas cancer (Li et al, 2009), hepatocellular cancer (Hassan et al, 2010), ovarian cancer (Bodmer et al, 2011), and breast cancer (Decensi et al, 2010). Metformin use has been associated with an improved survival in patients with pancreatic cancer (Sadeghi et al, 2011) and lung cancer (Gagnon et al, 2009). In patients with CRC cancer treated with chemotherapy, metformin was associated with an improved survival rate (Bansal et al, 2011). However, a retrospective review demonstrated that metformin did not significantly impact the outcome of survival of patients when used in the adjuvant setting in triple receptor-negative breast cancer (Bayraktar et al, 2011). In patients with prostate cancer, for which the association between increased risk and DM is less certain, an improved survival was not observed with the use of metformin (Azoulay et al, 2011).

The mechanism whereby metformin reduces glucose levels in diabetic patients is not entirely clear. However, it has been recently demonstrated to impair mitochondrial ATP production leading to the activation of liver kinase B1 (LKB1)-5' AMP-activated protein kinase (AMPK; El-Mir et al, 2000; Hawley et al, 2010). This leads to a decrease in energy-consuming processes in order to restore ATP levels (Kahn et al, 2005). Metformin LKB1 activation in human cancer cell lines in vitro is associated with inhibition of the mammalian target of rapamycine (mTOR), with subsequent reduced cellular proliferation (Shaw et al, 2004a,b; Dowling et al, 2006; Zakikhani et al, 2006). Thus, in cancer cells metformin inhibited insulin-stimulated mTOR activation and proliferation in an AMPK-dependent manner (Engelman and Cantley, 2010; Pollak, 2010). In vitro metformin has also been demonstrated to induce apoptosis in human ovarian cancer cell lines by directly activating caspases 3/7, downregulating Bcl-2 and Bcl-xl expression, whereas upregulating Bax and Bad expression (Yasmeen et al, 2011). Metformin may also potentially have an immunomodulatory role. Work is ongoing to determine the likely most relevant anti-cancer mechanism of metformin in diabetic patients.

Based upon these epidemiologic observations, as well as significant preclinical data suggesting a cancer prevention and therapeutic anti-cancer role for metformin in certain malignancies, a National Cancer Institute of Canada prospective randomised trial in early breast cancer has been initiated (Parulekar et al, 2011). Future prospective trials will be required in type II DM patients with CRC to confirm these retrospective findings of a survival benefit associated with the use of metformin in type II DM patients with CRC.

\section{REFERENCES}

Azoulay L, Dell'Aniello S, Gagnon B, Pollak M, Suissa S (2011) Metformin and the incidence of prostate cancer in patients with type 2 diabetes. Cancer Epidemiol Biomarkers Prev 20(2): 337-344

Bailey CJ, Turner RC (1996) Metformin. N Engl J Med 334(9): 574-579

Bansal M, Siegel E, Govindarajan R (2011) The effect of metformin on overall survival of patients with colorectal cancer treated with chemotherapy. I Clin Oncol 29: Presented at: American Society of Clinical Oncology, 4-8 June 2011, Chicago, IL, USA (abstract 2608).

Bayraktar S, Hernadez-Aya LF, Lei X, Meric-Bernstam F, Litton JK, Hsu L, Hortobagyi GN, Gonzalez-Angulo AM (2011) Effect of metformin on survival outcomes in diabetic patients with triple receptor-negative breast cancer. Cancer 118(5): 1202-1211

Bodmer M, Becker C, Meier C, Jick SS, Meier CR (2011) Use of metformin and the risk of ovarian cancer: a case-control analysis. Gynecol Oncol 123(2): $200-204$

Currie CJ, Poole CD, Gale EA (2009) The influence of glucose-lowering therapies on cancer risk in type 2 diabetes. Diabetologia 52(9): $1766-1777$

Decensi A, Puntoni M, Goodwin P, Cazzaniga M, Gennari A, Bonanni B, Gandini S (2010) Metformin and cancer risk in diabetic patients: a systematic review and meta-analysis. Cancer Prev Res (Phila) 3(11): $1451-1461$

Dowling RJ, Zakikhani M, Fantus IG, Pollak M, Sonenberg N (2006) Metformin inhibits mammalian target of rapamycin-dependent translation initiation in breast cancer cells. Cancer Res 66: 10269-10273

El-Mir MY, Nogueira V, Fontaine E, Avéret N, Rigoulet M, Leverve X (2000) Dimethylbiguanide inhibits cell respiration via an indirect effect targeted on the respiratory chain complex I. J Biol Chem 275(1): $223-228$

Engelman JA, Cantley LC (2010) Chemoprevention meets glucose control. Cancer Prev Res (Phila) 3: 1049-1052

Gagnon B, Roseman M, Kasymjanova G, MacDonald N, Kreisman H, Small D (2009) Protective effect of metformin in lung cancer patients. J Clin Oncol 27: Presented at: American Society of Clinical Oncology, 29 May-2 June 2009, Orlando, FL, USA (abstract 22063).
Golan T, Javle M (2011) Targeting the insulin growth factor pathway in gastrointestinal cancers. Oncology (Williston Park) 25(6): 518-526

Hassan MM, Curley SA, Li D, Kaseb A, Davila M, Abdalla EK, Javle M, Moghazy DM, Lozano RD, Abbruzzese JL, Vauthey JN (2010) Association of diabetes duration and diabetes treatment with the risk of hepatocellular carcinoma. Cancer 116(8): 1938-1946

Hawley SA, Ross FA, Chevtzoff C, Green KA, Evans A, Fogarty S, Towler MC, Brown LJ, Ogunbayo OA, Evans AM, Hardie DG (2010) Use of cells expressing gamma subunit variants to identify diverse mechanisms of AMPK activation. Cell Metab 11: 554-565

Kahn BB, Alquier T, Carling D, Hardie DG (2005) AMP-activated protein kinase: ancient energy gauge provides clues to modern understanding of metabolism. Cell Metab 1: 15-25

Landman GW, Kleefstra N, van Hateren KJ, Groenier KH, Gans RO, Bilo HJ (2010) Metformin associated with lower cancer mortality in type 2 diabetes: ZODIAC-16. Diabetes Care 33(2): 322-326

Larsson SC, Orsini N, Wolk A (2005) Diabetes mellitus and risk of colorectal cancer: a meta-analysis. J Natl Cancer Inst 97(22): 1679-1687

Lee JH, Kim TI, Jeon SM, Hing SP, Cheon JH, Kim WH (2011) The effects of metformin on the survival of colorectal cancer patients with diabetes mellitus. Int J Cancer; e-pub ahead of print 12 September 2011; doi: $10.1002 /$ ijc. 26421

Li D, Yeung SC, Hassan MM, Konopleva M, Abbruzzese JL (2009) Antidiabetic therapies affect risk of pancreatic cancer. Gastroenterology 137(2): 482-488

Ma J, Pollak MN, Giovannucci E, Leavitt A, Tao Y, Gaziano JM, Stampfer MJ (1999) Prospective study of colorectal cancer risk in men and plasma levels of insulin-like growth factor (IGF)-I and IGF-binding protein-3. J Natl Cancer Inst 91(7): 620-625

Maki RG (2010) Small is beautiful: insulin-like growth factors and their role in growth, development, and cancer. J Clin Oncol 28(33): 4985-4995

Meyerhardt JA, Catalano PJ, Haller DG, Mayer RJ, Macdonald JS, Benson III $A B$, Fuchs CS (2003) Impact of diabetes mellitus on outcomes in patients with colon cancer. J Clin Oncol 21: 433-440

Parulekar W, Chen BE, Elliott C, Shepherd LE, Gelmon KA, Pritchard KI, Whelan TJ, Ligibel JA, Hershman DL, Mayer IA, Hobday TJ, Rastogi P, 
Lemieux J, Ganz PA, Stambolic V, Goodwin PJ (2011) A phase III randomized trial of metformin versus placebo on recurrence and survival in early-stage breast cancer. J Clin Oncol 29(suppl): (abstr TPS103)

Pollak M (2010) Metformin and other biguanides in oncology: advancing the research agenda. Cancer Prev Res (Phila) 3: 1060-1065

Sadeghi N, Abbruzzese JL, Yeung SJ, Hassan M, Li D (2011) Effect of metformin on survival of diabetic patients with pancreatic adenocarcinoma. J Clin Oncol 29: Presented at: American Society of Clinical Oncology, 4-8 June 2011, Chicago, IL, USA. Abstract 4063

Shaw RJ, Bardeesy N, Manning BD, Lopez L, Kosmatka M, DePinho RA, Cantley LC (2004a) The LKB1 tumor suppressor negatively regulates mTOR signaling. Cancer Cell 6: 91 - 99

Shaw RJ, Kosmatka M, Bardeesy N, Hurley RL, Witters LA, DePinho RA, Cantley LC (2004b) The tumor suppressor LKB1 kinase directly activates AMP-activated kinase and regulates apoptosis in response to energy stress. Proc Natl Acad Sci USA 101: 3329-3335

Siddiqui AA, Maddur H, Naik S, Cryer B (2008) The association of elevated $\mathrm{HbA} 1 \mathrm{c}$ on the behavior of adenomatous polyps in patients with type-II diabetes mellitus. Dig Dis Sci 53: $1042-1047$
Surveillance Epidemiology and End Results (2011) Stat fact sheets: colon and rectum. http://seer.cancer.gov/statfacts/html/colorect.html (accessed 4 October 2011)

van de Poll-Franse LV, Houterman S, Janssen-Heijnen ML, Dercksen MW, Coebergh JW, Haak HR (2007) Less aggressive treatment and worse overall survival in cancer patients with diabetes: a large population based analysis. Int J Cancer 120: 1986-1992

Venkateswaran V, Haddad AQ, Fleshner NE, Fan R, Sugar LM, Nam R, Klotz LH, Pollak M (2007) Association of diet-induced hyperinsulinemia with accelerated growth of prostate cancer (LNCaP) xenografts. J Nat Cancer Inst 99(23): 1793 - 1800

Vigneri P, Frasca F, Sciacca L, Pandini G, Vigneri R (2009) Diabetes and cancer. Endocr Relat Cancer 16: $1103-1123$

Yasmeen A, Beauchamp MC, Piura E, Segal E, Pollak M, Gotlieb WH (2011) Induction of apoptosis by metformin in epithelial ovarian cancer: involvement of the Bcl-2 family proteins. Gynecol Oncol 121: 492-498

Zakikhani M, Dowling R, Fantus IG, Sonenberg N, Pollak M (2006) Metformin is an AMP kinase-dependent growth inhibitor for breast cancer cells. Cancer Res 66: 10269-10273

This work is published under the standard license to publish agreement. After 12 months the work will become freely available and the license terms will switch to a Creative Commons Attribution-NonCommercial-Share Alike 3.0 Unported License. 